\title{
Effects of Social Exclusion on Agriculture Activities of Rural Women in Ahoada Agricultural Zone of Rivers State.
}

\author{
Ifeanyi-obi C.C, Olatunji S.Oand Akpala J. \\ Department of Agricultural Economics and Extension Faculty of Agriculture, University of Port Harcourt.
}

\begin{abstract}
The study assessed the effects of social exclusion on agricultural activities of rural women in Ahoda agricultural zone of River State. Data was collected with the use of structured questionnaire from randomly selected 80 registered women and was analyzed using descriptive statistical tools namely frequency distribution, percentages and mean. Result shows that 56\% fall between the age brackets of $41-50,94 \%$ were married, $55.3 \%$ spent at most 6 years in school, 15.5\% earn above \$50,000 on a monthly basis, 47.4\% have more than $10 y e a r s$ farming experience while 58\% maintained household size of 1-5persons. Majority (92.4\%) of the women were farmers, have more than 2 hectres of lands(66.3\%) and employ mixed farming activity(45.0\%). The major aim of production was for both sales and consumption (61.4\%). Lack of access to major agricultural assets $(90.0 \%)$, extension services $(81.2 \%)$ and information source $(81.2 \%)$ were the major type of exclusion severely suffered by these women. Denial of access to agricultural information (mean=3.62) and ownership of agric assets (mean $=3.62$ ) and limitation of participation in decision making process in community (mean3.90) were the major effects of social exclusion suffered by these women.

Based on the findings of the study it was recommended that government should put in place policies that will curtail social exclusion of women and as well give them more opportunity and right to agricultural assets and information.
\end{abstract}

Keywords: Social exclusion, rural women, agricultural activities, effects

\section{Introduction}

Agricultural sector is one of the most potentially viable sectors of the Nigeria economy. Particularly in terms of its employment generation potentials as well as its contribution to Nation's Gross domestic product (GDP) and export revenue earnings. Agriculture in Nigeria is a major branch of the economy in Nigeria providing employment for $70 \%$ of the population. The sector is being transformed by commercialization at the small, medium and large-scale enterprise levels. (Wikepedia, 2013). The important benefits of the agricultural sector to Nigerian's economy include: the provision of food, contribution to the Gross domestic product (GDP), provision of employment, provision of raw materials for agro-allied industries, and generation of foreign earnings (until the early 1970s, agriculture exports were the main source of foreign exchange earnings). (Nkonya \& Philips, 2009).

Social exclusion refers to process in which individuals or entire communities of people are systematically blocked from rights, opportune and resources (example housing, democratic participation and due process that are normally available to members of society and which are due to social integration (Wikipedia 2013). In other words, social exclusion is a multidimensional process of progressive social rapture, detaching group and individuals from social relations and institution and preventing them from full participation in the normal prescribed activities of the society in which they live (Wikipedia 2013). The outcome of social exclusion is that affected individuals or communities are prevented from participating fully in the economic social and political life of the society (Hilarry, 2007).

Women are taking larger and more defined roles on farms and in agribusiness (Agweb.com, 2013). More women are becoming key leaders in farm operators, according to census data women operators have increased by $20 \%$. Globally $70 \%$ of all farmers are women (Agweb.com, 2013) and in Rivers State the case is still same as rural women provide over $65 \%$ of the labour force, contribute significantly in home keeping, childcare, farm work and achievement of rural development programmes (RISADEP,2002). Despite the fact that women make up over $75 \%$ of agricultural workers and livestock keepers in developing countries and are responsible for their families food security, they face significant difficulties in accessing natural resources, securing proper ownership, knowledge, service, and markets which hinder their productive capacity (Nnadi and Akwiwu, 2005; Ukpongson,2006; Olawoye, 2007; Asodike,2009; Anyaoha 2012). Women's role in agricultural operation is very significant. They contribute about three-fourth of the labour required for agriculture operations (Chandy, 2013). Women play an extremely important role in agricultural development accounting for an estimated 60-70 
percent of the labour forces thus playing a pivotal role in sustaining economy and this go a long way to reveal the very crucial role of women in the agricultural sector (Sen, 1998 and Meyer 2000). In rural areas where most of the world hungry people live, women produce most of food consumed locally, their contribution could be much better if they have equal access to essential resources and services such as credit facilities and training. Food production and supply companies typically set up contracts with men, with an implicit understanding that wives will provide some labour harvesting food. If women are excluded from basic agricultural inputs or resources in general, there will be a limit in the extent they can attain in food production thereby reducing the level of farm output generated by women. This will eventually turn the women in agriculture into subsistence farmers who can only provide food for their families but limiting their ability to generate income for themselves through the sales of the farm produce. Top Guide on Social Exclusion, (2012) stated that the exclusion of women from land ownership result in a decrease in food security and low productivity. Eldis, (2000) in the same view noted that the exclusion of women from access to natural resources result to a decrease in the standard of life of many farm families as women depend on the income they generate from agricultural activities to care for their families. Also the exclusion of women from policy making in agriculture increase the ignorance of women on basic policy guiding agricultural sector. Upholding women involvement in policy making can be a sure way of improving women's involvement and participation in identifying and developing food security project and can also help them to become aware of their right to some agricultural input e.g. land. The report of the world water day, 2012 stated that women despite making up about $63 \%$ of the agricultural workforce across the globe still have limited participation and ownership rights within agriculture. It further stated that if women were given more opportunities/rights in farm and farming techniques, both family life and entire community would benefit.

Furthermore, research have shown that there is a significant correlation between agriculture and the Gross Domestic Product (GDP) of the country, hence an exclusion of $70 \%$ labour force in agriculture will drastically reduces the Gross Domestic Product of that country, resulting to underdevelopment and increase in poverty level of that country. FAO, (2011) stated that Agriculture is underperforming in many developing countries for a number of reasons among these is the fact that women lack the resources and opportunities they need to make the most productive use of their time. It went further to explain that women are farmers, workers and entrepreneurs, but almost everywhere they face more severe constraints than men in accessing productive resources, market and services. This "gender gap" hinders their productivity and reduces their contribution to the agricultural sector and to the achievement of broader economic and social development goals. Closing the gender gap in agriculture would produce significant gains for society by increasing agricultural productivity, reducing poverty and hunger and promoting economic growth.

It is against this background that this research work assessed the social exclusion of women and its effect on their agricultural productivity with a view to generate vital information that will be helpful to government, developmental bodies, agencies in tackling the problem of social exclusion.

\section{Objectives of the study}

The general objective of this study was to assess the social exclusion of women and its effects on agricultural activities in Ahoda Agriculture zone of River State.

The specific objectives were to:

1. Described the socio-economic characteristics of women in the study area.

2. Ascertained whether women are socially excluded

3. Identified the nature of social exclusion suffered by women in the study area.

4. Determined the effect of social exclusion on their agricultural productivity.

\section{Research methodology}

The study was conducted in Ahoada agricultural zone of Rivers state which is one of the 23 local government areas in Rivers State. Ahoada zone consist of four blocks and 15 circles or cells. For operational convenience, the Rivers state ADP is divided into zones. These are zone 1, zone II, and zone III, which headquarters are Nchia, Ahoada and Degema respectively. Each of these zones is further divided into areas, block and cells. The activities of the RISADEP are implemented at the field level but the programme is conducted at the head quarters where most people operating at the block are gender based otherwise called women in agriculture projects.

The population of the study includes all registered women farmers in Ahoada agricultural zone of Rivers State. Multi-stage sampling technique was used to select the sample for the study. In the first stage, out of the four blocks in the zone, two were randomly selected. Secondly, from each of the selected blocks, three circles were randomly selected giving a total of 6 circles/cells for the study. Lastly a total number of 80 women farmers were proportionately from the 6 circles. 
Data was collected using interview schedule and analysed with descriptive statistical tools

\section{Socio economic characteristics of agricultural women}

\section{Result and discussion}

The result in Table 1 below shows that $4 \%$ of the rural women falls between the age brackets of less than $30 y e a r s, 11 \%$ were between the ages of $31-40$ years, $56 \%$ were between $41-50$ years and $29 \%$ were above 30 years. This reveals that majority of the rural women used for the study falls within the age brackets of 4150years. It was also shown that $94 \%$ of the women are married while $6 \%$ are single.

Furthermore, it was shown that $54 \%$ of the women spent between 1-6years in school, 35\% spent 7-13 years while $11 \%$ spent above 13 years in school. This implies that majority of the rural women used for the study had at most primary education. Illiteracy has been a major problem with farmers in Nigeria as majority of them are illiterates thereby find it difficult to harness educative innovations brought to them through channels like newspapers, leaflets etc.

Only $15.5 \%$ earn more than $\$ 50,000$ on monthly basis showing that only very few rural women live above poverty level. Relatively good numbers $(47.4 \%)$ of the women have more than 10years faring experience.

As regards household size, $58.7 \% \%$ has household size of between 1-5 persons, $40 \%$ has $6-10$ persons and $1.3 \%$ has household size of at least ten persons. This is an indication that majority of the rural women used for the study maintained an average household size. Farming (93\%) was

Shown to be their major occupation. This ascertains the fact that farming is the major livelihood activity of the rural people especially women. Only $12.5 \%$ had at least five hectres of land as their farmsize. This shows that majority of the women were producing on subsistence level. Also the Table went further to show the major farming activities women engage in, it was shown that $45 \%$ practice mixed farming, $18 \%$ practice livestock farming, $27 \%$ practice crop production while $10 \%$ practice fishery. This shows that majority of the women engage in mixed farming practice in other to produce food for both sales and consumption. Furthermore as regards aim to production, result show that $61 \%$ of the women have both sale and consumption as their major aim of production.

Table 4.1: Distribution of Socio Economic Characteristics Agricultural Women.

\begin{tabular}{|c|c|c|c|}
\hline S/No & Variable & Frequency & Percentage \\
\hline \multirow[t]{5}{*}{1.} & Age & & \\
\hline & $>30$ & 3 & 3.9 \\
\hline & $31-40$ & 9 & 11.1 \\
\hline & $41-50$ & 45 & 56.3 \\
\hline & Above 50 & 23 & 28.7 \\
\hline \multirow[t]{3}{*}{2.} & Martial status & & \\
\hline & Single & 4 & 5.8 \\
\hline & Married & 76 & 94.2 \\
\hline \multirow[t]{5}{*}{3.} & No of years spent in school & & \\
\hline & No formal education & & \\
\hline & $1-6$ & 67 & 54.3 \\
\hline & $7-13$ & 9 & 34.7 \\
\hline & Above 13years & 4 & 11.0 \\
\hline \multirow[t]{7}{*}{4.} & Monthly income & & \\
\hline & $\leq 10,000$ & 9 & 11.2 \\
\hline & $11,000-20,000$ & 17 & 21.2 \\
\hline & $21,000-30,000$ & 19 & 23.5 \\
\hline & $31,000-40,000$ & 13 & 16.2 \\
\hline & $41,000-50,000$ & 10 & 12.4 \\
\hline & Above 50,000 & 12 & 15.5 \\
\hline \multirow[t]{5}{*}{5.} & How long have you been farming & & \\
\hline & $\leq 5$ years & 42 & 52.6 \\
\hline & $6-10$ & 23 & 28.6 \\
\hline & $11-15$ & 12 & 15.1 \\
\hline & Above 15 years & 3 & 3.7 \\
\hline \multirow[t]{4}{*}{6.} & Household size & & \\
\hline & $1-5$ & 47 & 58.7 \\
\hline & $6-10$ & 32 & 40.0 \\
\hline & Above 10 & 1 & 1.3 \\
\hline \multirow[t]{3}{*}{7.} & Major occupation & & \\
\hline & Farming & 74 & 92.5 \\
\hline & Non farming & 3 & 3.7 \\
\hline \multirow[t]{4}{*}{8.} & Size of farm (plots) & & \\
\hline & $1-2$ & 27 & 33.8 \\
\hline & $3-4$ & 43 & 53.8 \\
\hline & $5-6$ & 10 & 12.5 \\
\hline \multirow[t]{2}{*}{9.} & Major farm activity & & \\
\hline & Mixed farming & 36 & 45.0 \\
\hline
\end{tabular}


Effects of Social Exclusion on Agriculture Activities of Rural Women in Ahoada Agricultural ....

\begin{tabular}{|c|c|c|c|}
\hline & Livestock farming & 10 & 18.5 \\
\hline & Crop production & 27 & 26.8 \\
\hline & Fishery & 7 & 9.7 \\
\hline \multirow[t]{4}{*}{10.} & Major aim of production & & \\
\hline & Sales & 13 & 16.2 \\
\hline & Consumption & 17 & 22.2 \\
\hline & Both & 49 & 61.4 \\
\hline
\end{tabular}

Source: Field survey data 2014.

To ascertain whether women are socially excluded.

The Table below shows the distribution of women to ascertain whether they are socially excluded or not. Out of 80 rural women used for the study, result shows that $81.2 \%$ do not have access to information sources, $81.2 \%$ do not have access to extension services, $90 \%$ do not have access to ownership of basic agricultural asset, $77.5 \%$ are excluded from decision and policy making, $71.2 \%$ are excluded from belonging to useful association and 78.4 are excluded from financial services. The result therefore ascertained that rural women in the study area suffer social exclusion in different forms.

Table 4:2 Distribution of agricultural women to ascertain whether women are socially excluded.

\begin{tabular}{|c|c|c|c|}
\hline S/No & Variable & Frequency & Percentage \\
\hline \multirow[t]{3}{*}{1.} & I do not have access to information source & & \\
\hline & Yes & 65 & 81.2 \\
\hline & No & 15 & 18.8 \\
\hline \multirow[t]{3}{*}{2.} & I do not have access to extension services & & \\
\hline & Yes & 65 & 81.2 \\
\hline & No & 15 & 18.8 \\
\hline \multirow[t]{3}{*}{3.} & I do not have access to ownership of basic agricultural assets e.g. law. & & \\
\hline & Yes & 72 & 90.0 \\
\hline & No & 8 & 10.0 \\
\hline \multirow[t]{3}{*}{4.} & I am excluded from decision policy making & & \\
\hline & Yes & 62 & 77.5 \\
\hline & No & 18. & 22.5 \\
\hline \multirow[t]{3}{*}{5.} & I am excluded from belonging to useful associations & & \\
\hline & Yes & 57 & 71.2 \\
\hline & No & 23 & 28.8 \\
\hline \multirow[t]{3}{*}{6.} & I am excluded from financial services e.g. loans and insurance & & \\
\hline & Yes & 62 & 78.4 \\
\hline & No & 18 & 21.6 \\
\hline
\end{tabular}

Source: Field survey data 2014.

Level of social exclusion suffered by rural women in Ahoda agricultural zone of River state

Table 3 shows the level of social exclusion suffered by the rural women in the study area. Result shows that the agricultural women in the study area suffer severe social exclusion in the six areas used to capture social exclusion in the study. Specifically the women suffer severe exclusion in lack of access to information sources (mean $=3.42$ ), lack of access to extension services delivery (mean $=3.56$ ), lack of access to ownership of basic agricultural asset (mean $=3.71$ ), lack of participation in decision and policy making process (mean $=3.36$ ), denial of belonging to useful association (mean $=3.29)$ and lack of access to financial services $($ mean $=3.35)$.

Table 4:3 Distribution of ascertain the level of the social exclusion suffered by women.

\begin{tabular}{|c|c|c|c|c|c|c|c|}
\hline S/no & Statement & Very Severe & $\begin{array}{l}\text { Moderately } \\
\text { Severe }\end{array}$ & Severe & Not Severe & Mean & Remark \\
\hline 1. & $\begin{array}{l}\text { I do not have access to information } \\
\text { source }\end{array}$ & $44(55.0)$ & $26(32.6)$ & $5(6.2)$ & $5(6.2)$ & 3.42 & Severe \\
\hline 2. & $\begin{array}{l}\text { I do not have access to extension service } \\
\text { that can improve my agricultural } \\
\text { productivity }\end{array}$ & $46(57.5)$ & $34(42.5)$ & Nil & Nil & 3.56 & Severe \\
\hline 3. & $\begin{array}{l}\text { I do not have access to ownership of } \\
\text { basic agricultural assists e,g land }\end{array}$ & $56(70.0)$ & $22(28.0)$ & $2(2.0)$ & Nil & 3.71 & Severe \\
\hline 4. & $\begin{array}{l}\text { I am excluded from decision policy } \\
\text { making }\end{array}$ & $33(40.0)$ & $43(55.0)$ & $2(2.5)$ & $2(2.5)$ & 3.36 & severe \\
\hline 5. & $\begin{array}{l}\text { I am excluded from belonging to useful } \\
\text { association }\end{array}$ & $38(47.5)$ & $31(38.8)$ & $5(6.2)$ & $6(7.5)$ & 3.29 & severe \\
\hline 6. & $\begin{array}{l}\text { I am excluded from financial services } \\
\text { e.g. loans and insurances }\end{array}$ & $36(45.6)$ & $34(40.5)$ & $7(8.8)$ & $3(3.6)$ & 3.35 & severe \\
\hline
\end{tabular}

Source: Field survey, 2014

Effects of social exclusion on women's agricultural activities. 
Table four shows the effects of social exclusion on women's agricultural activities. Out of the 16 statements used to capture the effects of social exclusion on agricultural activities, the women agreed that it prevents them from assessing basic agricultural information ( mean $=3.62$ ), limits their participation in decision making processes $($ mean $=3.90)$, denied them ownership to agricultural asset (mean $=3.68)$, reduces my chances of securing financial services $($ mean $=3.51)$, robs me of collateral to procure loan $($ mean $=3.65$ ), reduces my capacity to procure important agricultural equipment (mean $=4.46$ ), deprive me from transcending from subsistence farming to market oriented agricultural production (mean=3.55), limits my access to improved farm inputs (mean $=3.45)$, limits me to sell my agricultural products in local markets $($ mean $=3.26)$, excludes me from agricultural extension services $($ mean $=3.31)$, denies me access to membership of official and beneficial co-operative society $($ mean $=3.27)$, results to reduced agricultural productivity (mean $=3.67$ ), increases my poverty level generally (mean $=3.23$ ), results to poor nutrition and well being of my family (mean $2.91)$ and results to poor and slow adaptation to climate change (mean $=3.45$ ). This implies that women suffer many versions of social exclusion which impact negatively both on their agricultural production and general wellbeing.

Table 4:4 Distribution of women according to the effects of social exclusion on their agricultural activities.

\begin{tabular}{|c|c|c|c|c|c|c|c|}
\hline S/no & Statement & Strongly agree & Agree & Disagree & $\begin{array}{l}\text { Strongly } \\
\text { disagree }\end{array}$ & Mean & Remark \\
\hline 1. & $\begin{array}{l}\text { It prevents one from assessing basic } \\
\text { agricultural information }\end{array}$ & $52(65.0)$ & $22(27.5)$ & $6(7.5)$ & Nil & 3.62 & Agree \\
\hline 2. & $\begin{array}{l}\text { It limit my participation in decision } \\
\text { making processes in my community }\end{array}$ & $41(51.2)$ & $33(41.3)$ & $6(2.5)$ & Nil & 3.90 & Agree \\
\hline 3. & $\begin{array}{l}\text { I am denied ownership to agriculture } \\
\text { assets }\end{array}$ & $54(67.5)$ & $23(28.8)$ & $3(3.6)$ & Nil & 3.68 & Agree \\
\hline 4. & $\begin{array}{l}\text { It reduces my chances of securing } \\
\text { financial services e.g. loans, insurant } \\
\text { subsidies etc }\end{array}$ & $41(51.2)$ & $33(41.3)$ & $6(7.5)$ & Nil & 3.51 & Agree \\
\hline 5. & It robs me of collateral to procure loan & $51(63.8)$ & $29(36.2)$ & Nil & Nil & 3.65 & Agree \\
\hline 6. & $\begin{array}{l}\text { It reduces my capacity to procure } \\
\text { important agricultural equipments }\end{array}$ & $38(47.5)$ & $38(47.5)$ & $4(5.0)$ & Nil & 3.46 & Disagree \\
\hline 7. & $\begin{array}{l}\text { It deprive me from transcending from } \\
\text { subsistence farming to commercial } \\
\text { farming. }\end{array}$ & $41(51.2)$ & $33(41.5)$ & $2(2.5)$ & $4(4.8)$ & 3.43 & agree \\
\hline 8. & $\begin{array}{l}\text { It discourage me from investing more } \\
\text { time and resources in agricultural } \\
\text { production }\end{array}$ & $45(56.4)$ & $33(41.0)$ & Nil & $3(3.6)$ & 3.55 & Agree \\
\hline 9. & $\begin{array}{l}\text { It limits my access to improved farm } \\
\text { inputs e.g. seedlings }\end{array}$ & $35(43.8)$ & $45(56.2)$ & Nil & Nil & 3.45 & agree \\
\hline 10. & $\begin{array}{l}\text { It limit me to sell my agricultural } \\
\text { products in local markets }\end{array}$ & $33(41.2)$ & $32(40.0)$ & $9(11.3)$ & $6(7.5)$ & 3.26 & agree \\
\hline 11. & $\begin{array}{l}\text { It excludes me from agricultural } \\
\text { products extension services }\end{array}$ & $32(40.0)$ & $37(46.2)$ & $11(13.8)$ & Nil & 3.31 & agree \\
\hline 12. & $\begin{array}{l}\text { am denied access to membership of } \\
\text { official and beneficial crop society }\end{array}$ & $35(43.8)$ & $31(38.6)$ & $8(10.0)$ & $6(7.6)$ & 3.27 & agree \\
\hline 13. & $\begin{array}{l}\text { It results to reduced agricultural } \\
\text { productivity }\end{array}$ & $53(66.2)$ & $21(26.3)$ & $6(7.5)$ & Nil & 3.67 & Agree \\
\hline 14. & It increases my poverty level & $26(32.5)$ & $43(53.7)$ & $11(13.8)$ & Nil & 3.23 & agree \\
\hline 15. & $\begin{array}{l}\text { It results to poor nutrition and well } \\
\text { being of my family }\end{array}$ & $20(25.0)$ & $36(45.0)$ & $24(30.0)$ & $6(7.5)$ & 2.91 & agree \\
\hline 16. & $\begin{array}{l}\text { It results to poor and slow adaptation } \\
\text { to climate change }\end{array}$ & $41(51.2)$ & $28(35.0)$ & $11(13.8)$ & Nil & 3.45 & agree \\
\hline
\end{tabular}

Source: Field survey, 2014

\section{Conclusion And Recommendations}

Social exclusion refers to process in which individuals or entire communities of people are systematically blocked from rights, opportune and resources. Based on the result of this study, it was concluded that rural women in Ahoda agricultural zone suffer varying versions of social exclusion at various level. The study recommends that government should establish social protection programmes that will help in reducing the level of social exclusion suffered by these women. Also, policies that give women access to basic agricultural assets should be put in place to enable these rural women have access to basic agricultural assets that will improve their agricultural production. 


\section{References}

[1]. Adatom, Carter, M and May .J. (2004), Sense in Sociability; Social Exclusion Persistent Poverty in South Africa. Accessed on 14 December 2013

[2]. Anyoha, N. O., Asiabaka, C. C., Chikaire, J., Ifeanyi-Obi, C. C. and Onoh, P. A. (2012). Factors Influencing Rural Women`s Participation in Developmental Programmes in Rivers State, Nigeria: A Key for Social Exclusion Elimination. International Journal of Applied Research and Technology. 1(8): 55 - 60.

[3]. Asodike, J.D, (2009). Gender inequality; Barrier to sustainable Development: Journal of International Gender Studies (JIGS). No 5 Pp. 211-213.

[4]. Bird K (2007) The Integrational Transmission of Poverty and an overview . Overseea Development Institute, and Poverty research center, Marchester United Kingdom.

[5]. Caroll, K. (2012) Social Exclusion. Topic Guiders to Social Exclusion Retrieved from www.gsdrc.org/topic.guide on $30 / 9 / 2013$.

[6]. Chandy Hoke (2010) Some Reflections on the Notion of Inclusion Political Part a Perspective from Ahmedals, Working. Paper no 71 Crisis State Research Centre London.

[7]. Chandy, P. (2012) The Role of Women in Agriculture. World Farmers Organization (WHO).FAO-Viale Delle Tenme di Caracalla, Malaysia Room Italy. Global Research Team. Retrieved from http ://www.Ica.Coop/en/events-60 on 6/1/2012.

[8]. Dani, A.A and Dehaan A, (2008) Social Policy in Development Content; Situated Inequalities and Inclusion Institution. dana and hana, 2008 inclusion state social policy and structural inequalities, world bank, Washington dc, pp 1-37.

[9]. Elddis, D. (2000) Too Much and Too Little? Debates on Surplus Food. Sustainability. The Alliance for Better Food and Farming National Council of Women National Farmers Retrieved from www.sustainweb.org/pdf/pov. on 31/12/2013.

[10]. Food and Agriculture Organization (2011) The role of Women in Agriculture. SOFA Team and Cheryl Doss. ESA Working Paper no 1-02 (March) FAO UN.

[11]. Food and Agriculture Organization (2011) The Vital role Of women in Agriculture and Rural Development, 1 Rome.

[12]. Food And Agriculture Organization of the United Nation, Rome (2011) The State of Food and Agriculture in IDS bulletin 31(4).

[13]. Hilary Silver "Social Exclusion: Comparative Analysis of Europe and Middle East Youth Middle East Youth Initiative (MEYI). Retrieved from www.shobabinclusion.com on 22/2/2014.

[14]. Kabeer, N. (2000) Social Exclusion Poverty and Discrimination; Towards an Analytical Frame Work ids bulletin 314, institute of development studies.

[15]. Mcdevit .A. (2009), The Impact of Countries on Women Education, Research Report, Governance and Social Development Research Centre Brimighon.

[16]. Meyer, L. (2002). "Statistics on social exclusion: the EU methodological approach", Eurostat, unit E2 living conditions.

[17]. Moncrieffe, (2007) Icebelling, Power, and Accountability how and why our category matter in moncrieffe, J and Eyben, the power of labeling, earthscan.

[18]. Narayam, D.E. (2007). Agency, Opportunity Structure and Poverty Escapes. World Water Day (2012). Global Marshal Foundation.

[19]. Nkoya, E.M. \& Philip, D. (2009) Impacts of Community Driven Development Programs on Income and Asset Acquisition in Africa: The Case of Nigeria International Association of Agricultural Economics Beijing, China.

[20]. Nkoya, Philis (2009), Understanding Gender Difference in Agricultural Productivity in Nigeria.

[21]. Nnadi, F. N. and Akwiwu, C. D. (2005). Rural women's response to selected crop production technologies in Imo State, Nigeria. In Matthews- Njoku E. C. and Adesope O. M. (eds) Global Approaches to Extension Practice. Vol. 1.

[22]. Olawoye, J. E. (2007). "Difficulties of Rural women in securing resources for agricultural production". Monograph, Ibadan University of Ibadan

[23]. Oommen Chandy (2013), Scaling up Agricultural Technologies.

[24]. PAV Ednews (2012) Empowering for Peace Through Leadership in Agribusiness and Sustainability Project: Eradicating Poverty in Rural Communities Sanf Leopold, Barcelona Retrieved from htt://www.gunningnetwork.com on 24/2/2014.

[25]. Saith. R, (2007), Social Exclusion: the Concept and Application of Developing Countries ; In Stewart F, Saith R and Harris white. Defining poverty in the developing world, Palgrave, pp 75-90.

[26]. Salamis, (2004) Exclusion and Identity in Lebanon Palestinian Refugee Camp; A Story of Conflict, Environment and Urbanization, Volume Number 2, pp 3 9-48.

[27]. Tilly .C. (2007), Poverty and Politics of Exclusion of Narayan, D. and Petesh, P.(eds) Moving out of Poverty, World Bank Publications, Washington dc.Topic Guide on Social Exclusion (2012)

[28]. Room, G . (1995) . Beyond the threshold: the measurement and analysis of social exclusion, Policy Press, Bristol. Rivers State Agricultural Developement Programme, Nigeria (2002) Report of year1997 to 2001 crop Area and yield survey

[29]. Ukpongson, M.O. (2006). Gender participation in rural development planning, implementation and monitoring in Niger Delta Community, Nigeria. Ph.D. Thesis, Federal University of Technology Owerri, Nigeria pp 123-124

[30]. Weigo (2002) Report of the Africa Regional work Shop on food zing and processing and minor first product global value chains Kampak, Uganda, Africa centre for gender and development women in information employment globalizing and organizing. 